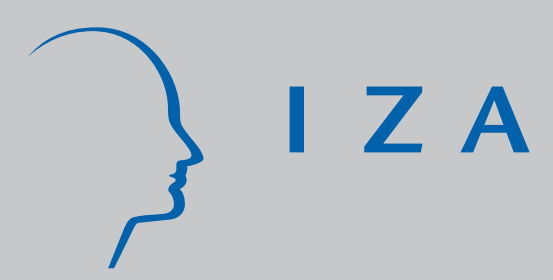

IZA DP No. 5849

Health Impaired Employees' Job Satisfaction:

New Evidence from Athens, Greece

Nick Drydakis

July 2011 


\title{
Health Impaired Employees' Job Satisfaction: New Evidence from Athens, Greece
}

\author{
Nick Drydakis \\ University of Patras, \\ Scientific Centre for the Study of Discrimination, Athens \\ and IZA
}

\section{Discussion Paper No. 5849 \\ July 2011}

IZA

P.O. Box 7240

53072 Bonn

Germany

Phone: +49-228-3894-0

Fax: +49-228-3894-180

E-mail: iza@iza.org

Any opinions expressed here are those of the author(s) and not those of IZA. Research published in this series may include views on policy, but the institute itself takes no institutional policy positions.

The Institute for the Study of Labor (IZA) in Bonn is a local and virtual international research center and a place of communication between science, politics and business. IZA is an independent nonprofit organization supported by Deutsche Post Foundation. The center is associated with the University of Bonn and offers a stimulating research environment through its international network, workshops and conferences, data service, project support, research visits and doctoral program. IZA engages in (i) original and internationally competitive research in all fields of labor economics, (ii) development of policy concepts, and (iii) dissemination of research results and concepts to the interested public.

IZA Discussion Papers often represent preliminary work and are circulated to encourage discussion. Citation of such a paper should account for its provisional character. A revised version may be available directly from the author. 
IZA Discussion Paper No. 5849

July 2011

\section{ABSTRACT \\ Health Impaired Employees' Job Satisfaction: New Evidence from Athens, Greece}

By utilizing the 2008 Athens Area Study (AAS) data set, this study investigates four aspects of job satisfaction - total pay, promotion prospects, respect received from one's supervisor, and total job satisfaction - between healthy and heath-impaired employees. Health impaired employees are found to be less satisfied according to all job satisfaction measures even when a large number of productivity features, and job characteristics are controlled for. The outcomes suggest also that women are more satisfied with their jobs than men are, regardless of health status. Moreover, the estimations show that health impaired employees' job satisfaction is affected more than healthy employees' job satisfaction by adverse mental health symptoms (life dissatisfaction). Finally, health impaired employees are found to become more satisfied with their jobs with time after disability onset. The study concludes that health impaired employees may have higher expectations about what they will obtain from their work, and that they may have job satisfaction adjustments.

JEL Classification: J10, J28

Keywords: health impairments, job satisfaction, ordered probit model, switching regression model, two-step quasi-likelihood exogeneity test

Corresponding author:

Nick Drydakis

Department of Economics

University of Patras

University Campus

26504 Rio

Greece

E-mail: ndrydakis@econ.soc.uoc.gr 


\section{Introduction}

Studies conclude that the analysis of employees' subjective well-being and the understanding of what makes different groups of workers satisfied can provide a number of insights into the most important labour market behaviours: productivity, absenteeism, quitting, work behaviour, and health (Green, 2010). The current study focuses on the analysis of the reported differentials of job satisfaction for healthy and health impaired employees by utilizing the 2008 Athens Area Study (AAS). As in Clark (1996) and Gazioglu and Tansel (2006) to determine whether a job satisfaction gap exists, the job satisfaction of health impaired employees is compared to the job satisfaction of healthy employees after accounting for various asymmetries.

The current AAS consists of telephone-based surveys. The data were gathered by the University of Piraeus, University of Central Greece and Panteion University of Social and Political Sciences. The 2008 AAS is one component of the Multi-City Study of the Scientific Center for the Study of Discrimination (SCSD). There are two types of individuals in the sample; the healthy (non-impaired) people and the health impaired people. As in the European Community Household Panel (1995-2001) to investigate the health condition, individuals were asked: 'The next question is about health condition: Do you have a chronic, over 12 months, physical or mental health problem, illness or disability?' The AAS sample includes also additional information regarding a broad list of objective health conditions, as well as, functional activities and other limitations in daily activities and instrumental activities because of their potential productivity-related limitations (see, Drydakis’s 2010 analysis). 
Four measures of job satisfaction are available in the AAS dataset. The measures are total pay (including any overtime or bonuses), promotion prospects, respect received from supervisors, and total job satisfaction. There are many methods of measuring job satisfaction, the most common of which is the Likert scale (1932). The AAS follows the format of a typical five-level Likert item. The job facet satisfaction question reads, 'I'm going to read you four aspects of jobs, and for each one, I'd like you to tell me which number best describes how satisfied or dissatisfied you are with that particular aspect of your own present job’ Employees are asked to rate each job aspect on a scale from 1, 'very dissatisfied' to 5, 'very satisfied'.

The present research makes a conceptual contribution to our understanding of health impaired employees in the Greek labour market. The AAS dataset includes a large number of control variables, such as education, age, job characteristics, objective health conditions and depression scale score. Some of these variables are correlated with job satisfaction, so their inclusion is important when studying the relation between health status and job satisfaction. The fruitful outcomes of this study highlight that the knowledge of the job satisfaction level of a minority population is useful for helping social scientists understand a wide array of important questions about the general condition of the labour market.

\section{Estimations}

The AAS sample consists of 10,705 healthy employees (81.9\%) and 2,350 healthimpaired employees (18.6\%). The descriptive statistics show that healthy employees have 
higher levels of job satisfaction than health-impaired employees in all specifications ${ }^{1}$. To analyse the four measures of 'job satisfaction', we consider an Ordered Probit model as in Clark (1997) and Gazioglu and Tansel (2006), which contains generally similar sets of personal characteristics but varying sets of job related characteristics as independent variables $^{2}$.

As shown in Table 1, health impaired employees are always less satisfied than healthy employees according to all measures of job satisfaction. The largest difference is found for satisfaction with promotion prospects followed by satisfaction with respect received from supervisor and satisfaction with total pay ${ }^{3}$. Many studies confirm that workplace conditions are crucial in determining employees' job satisfaction (Law and Wong, 1998; Burgen, 2004). Based on Locke’s Affect Theory (1976, 1984), how much one values a given facet of work moderates how dissatisfied one becomes when one's expectations are not met. We can suggest, then, that health impaired employees may have higher expectations about what they will obtain from their work. These outcomes should be of interest to workers and employers alike. Similarly, in the United Kingdom, Clark et al (1996) and Gazioglu and Tansel (2006) find that 'impaired health' has always a negative effect on employees' job satisfaction. Renaud (2002) and Uppal (2005) estimate the same pattern for Canadian employees.

\footnotetext{
${ }^{1}$ Descriptive statistics are available on request.

${ }^{2}$ Switching regression models suggested by Amemyia (1985) were employed to control for endogeneity of self-assessed health responses (see, Drydakis's analysis 2010). These controls turned to be statistically insignificant. Endogeneity and sensitivity analysis are available on request.

${ }^{3}$ With respect to the other exogenous variables of interest, the results are as expected.
} 
Table 1. Ordered Probit Estimates of Job Satisfaction

Table 1. Ordered Probit Estimates of Job total pay

Health status $^{\# 1}$

Functional activities ${ }^{\# 2}$

Daily living activities $\# 3$

Instrumental activities ${ }^{\# 4}$

Objective health illness $\# 5$

Adverse mental health

symptoms (CES-D 20 items) ${ }^{\# 6}$

Adverse mental health

symptoms (CES-D 20 items) $\mathrm{x}$

Health status

Years since disability onset

Years since disability onset $\mathrm{x}$

Health status

Wage

Women

Women $\mathrm{x}$ Health status

Age

Age $^{2}$

Married

Number of children

Immigrant

Minimum mandatory education

Graduation from high school

University or technical school

diploma

Computing

English

Driving

Actual working experience

White collar jobs

Blue collar jobs

Public occupations

Full time employment

Intercept

$\mathrm{R}^{2}$

Observations

$\begin{array}{ll}-0.236(0.020)^{* * *} & -0.404(0.024)^{* * *} \\ -0.084(0.013)^{* * *} & -0.085(0.014)^{* * *} \\ -0.075(0.002)^{* * *} & -0.073(0.002)^{* * *} \\ -0.031(0.008)^{* * *} & -0.028(0.005)^{* * *} \\ \text { Yes } & \text { Yes } \\ -0.021(0.004)^{* * *} & -0.021(0.005)^{* * *} \\ & \\ -0.031(0.007)^{* * *} & -0.028(0.007)^{* * *}\end{array}$

$0.024(0.003)^{* * *}$

$0.035(0.007)^{* * *}$

$1.176(0.026)^{* * *}$

$0.018(0.007) * * *$

$0.015(0.006)^{* * *}$

$-0.023(0.003)^{* * *}$

$0.0001(0.00001)^{* * *}$

$0.038(0.004)^{* * *}$

$0.017(0.014)$

$-0.028(0.003) * * *$

$-0.048(0.017) * * *$

$-0.053(0.009) * * *$

$-0.087(0.016) * * *$

-0.007 (0.006)

$-0.005(0.015)$

0.002 (0.010)

$-0.074(0.014) * * *$

$-0.022(0.003) * * *$

$0.049(0.021)^{* * *}$

$0.038(0.011)^{* * *}$

$0.024(0.010)^{* * *}$

$-3.205(0.149) * * *$

0.633

13,055
Satisfaction with

promotion prospects

$0.032(0.005)^{* * *}$

$0.038(0.004)^{* * *}$

$1.670(0.026)^{* * *}$

$0.016(0.008)^{* * *}$

$0.010(0.002)^{* * *}$

$-0.024(0.005)^{* * *}$

$0.0001(0.00001) * * *$

$0.042(0.005)^{* * *}$

$0.017(0.013)$

$-0.026(0.004) * * *$

$-0.046(0.014) * * *$

$-0.057(0.011) * * *$

$0.082(0.013)^{* * *}$

$-0.008(0.005)$

$-0.006(0.015)$

$0.002(0.011)$

$-0.078(0.013) * * *$

$0.063(0.024)^{* * *}$

$-0.013(0.004) * * *$

$0.039(0.016)^{* * *}$

$0.021(0.008)^{* * *}$

$-2.762(0.151)^{* * *}$

0.669

13,055

$\begin{array}{ll}\begin{array}{l}\text { Satisfaction with respect } \\ \text { received from one's }\end{array} & \begin{array}{l}\text { Total } \\ \text { job }\end{array} \\ \text { supervisor } & \text { satisfaction } \\ -0.271(0.014)^{* * *} & -0.293(0.017)^{* * *} \\ -0.083(0.017)^{* * *} & -0.089(0.015)^{* * *} \\ -0.075(0.004)^{* * *} & -0.074(0.003)^{* * *} \\ -0.030(0.006)^{* * *} & -0.027(0.004)^{* * *} \\ \text { Yes } & \text { Yes } \\ -0.023(0.008)^{* * *} & -0.019(0.005)^{* * *} \\ & \\ -0.027(0.005)^{* * *} & -0.026(0.006)^{* * *}\end{array}$

$0.030(0.008)^{* * *}$

$0.036(0.005) * * *$

$1.720(0.025)^{* * *}$

$0.018(0.007)^{* * *}$

$0.011(0.002)^{* * *}$

$-0.020(0.004) * * *$

$0.0001(0.00004)^{* * *}$

$0.035(0.006)^{* * *}$

$0.016(0.012)$

$-0.027(0.004) * * *$

$-0.051(0.015) * * *$

$-0.049(0.009)^{* * *}$

$0.086(0.016) * * *$

-0.007 (0.007)

$-0.006(0.014)$

$0.003(0.010)$

$-0.078(0.016)^{* * *}$

$0.058(0.023) * * *$

$-0.016(0.005)^{* * *}$

$0.035(0.011) * * *$

$0.022(0.010)^{* * *}$

$-2.821(0.146)^{* * *}$

0.629

13,055
$0.029(0.004)^{* * *}$

$0.037(0.007)^{* * *}$

$1.262(0.015)^{* * *}$

$0.017(0.006)^{* * *}$

$0.015(0.005)^{* * *}$

$-0.021(0.005)^{* * *}$

$0.0001(0.00004) * * *$

$0.037(0.008)^{* * *}$

$0.017(0.012)$

$-0.029(0.004) * * *$

$-0.047(0.011) * * *$

$-0.054(0.007) * * *$

$0.079(0.010)^{* * *}$

$-0.007(0.011)$

$-0.006(0.014)$

0.002 (0.009)

$-0.074(0.015)^{* * *}$

$0.048(0.021)^{* * *}$

$-0.036(0.008) * * *$

$0.033(0.008)^{* * *}$

$0.028(0.012)^{* * *}$

$-2.600(0.118) * * *$

0.611

13,055

Notes: Data Source, Athens Area Study (2008-2010)

${ }^{\# 1}$ chronic, over 12 months, physical or mental health problem, illness or disability

\#2 constraints when seeing, or/and hearing, speaking, lifting/carrying, using stairs, walking, or grasping small objects

\#3 constraints when getting around inside the home, or/and getting in or out of bed or chair, dressing, eating and toileting

${ }^{\# 4}$ constraints when going outside the home, or/and keeping track of money and bills, preparing meals, doing light housework,

taking prescription medicines in the right amount at the right time, and using the telephone

\#5 diabetes, or/and heart attack, arthritis, psychiatric problems, cancer

\#6 20 items describing major components of depressive symptomatology (e.g. depressed, not happy, lonely, did not enjoy life)

Each column is a separate regression.

Standard errors are in parenthesis. ***Significant at the 1\% level. ** Significant at the 5\% level. *Significant at the $10 \%$ level. 
In Table 1, we can also observe that women always report to have higher job satisfaction coefficients than males, regardless health status, even though in the AAS data set women receive lower hourly wages than men do. Indeed, Clark et al. (1997), SouzaPoza and Souza-Poza (2003), and Gazioglu and Tansel (2006) estimate women to be more satisfied with their work than men, perhaps because women have gained a better position in the market relative to their expectations; this is the so-called gender/job-satisfaction paradox (i.e., women receive lower wages than men do, but they are more satisfied at work than men are).

In equations for all four measures of job satisfaction, employees with more adverse mental health symptoms are always less satisfied at work than those who have fewer of these conditions ${ }^{4}$. The scale defined by the Center for Epidemiology Studies (CES-D, 20 items), measures the existence of adverse mental health symptoms, and studies have confirmed the validity and reliability of the score as a screening instrument for the evaluation of major depression, subjective well-being, and disposition (Irwin et al. 1999; Stanbury et al. 2006; Shenkman and Shmotkin; 2011). In this stage, it might be of further interest to estimate whether adverse mental health symptoms affect the job satisfaction of health impaired employees more or less strongly. A term that interacts health status with adverse mental health symptoms is added to the basic equation. The outcome suggests that health impaired employees' job satisfaction is affected more by these symptoms. Several review studies confirm this pattern (Rain et al, 1991; Faragher et al, 2005). Employers

\footnotetext{
${ }^{4}$ A two-step quasi-likelihood exogeneity test suggested by Rivers and Vuong (1988) and discussed in Wooldridge (2002) was employed to test whether the adverse mental health symptoms variable was endogenous in this step. All attempts brought no indications of endogeneity, rendering the framework appropriate.
} 
should seriously look at tackling the relations between job dissatisfaction and related mental health problems. This would be a wise investment given the potential substantial economic costs of dissatisfied employees (see Faragher et al., 2005).

Finally, in Table 1, we examine additional health status' interactive effects. We estimate positive relations between job satisfaction and years since disability onset. In other words, health impaired employees who have been disabled for a longer time have higher job satisfaction compared to health impaired employees who became disabled more recently. Comparable patterns are discussed in Oswald and Powdthavee (2008) who evaluate the idea that disabled people bounce back from utility shocks. A phenomenon sometimes described as hedonic adaptation (see, Frederick and Loewenstein, 1999; Lucas et al, 2003). It might be the case that simultaneous activation of the positive and negative affect systems generates an adaptive reaction among health impaired employees.

On average, if a variable such as job satisfaction contains useful information to predict behaviour and reflects the returns to labour market activity, it seems appropriate for social scientists to focus on this variable. Although the findings are strictly applicable only to the time and place from which the sample was drawn, this study has implications for understanding some of the patterns of health impaired employees' characteristics in the labour market.

\section{Conclusions}

This study has pursued the issue of differences in job satisfaction by examining the extent to which four aspects of job satisfaction - total pay, promotion prospects, respect received from one’s supervisor, and total job satisfaction - could vary between healthy and 
health impaired employees. By utilizing the Athens Area Study data set (2008) health impaired employees were found to be less satisfied according to all job satisfaction measures even when a large number of productivity features, and job characteristics are controlled for. The outcomes suggested also that women are more satisfied with their jobs than men are. Of further importance was the finding that health-impaired employees' job satisfaction is affected more than healthy employees' job satisfaction by adverse mental health symptoms (life dissatisfaction). Finally, health impaired employees were found to become more satisfied with their jobs with time after disability onset. The study concludes that health impaired employees may have higher expectations about what they will obtain from their work, as well as, they may have job satisfaction adjustments. 


\section{References}

Amemyia, T. (1985). Advanced Econometrics. Cambridge: Harvard University Press.

Bygren, M. (2004). Pay Reference Standards and Pay Satisfaction: What do Workers Evaluate their Pay Against? Social Science Research, 33:206-24.

Clark, A. (1996). Job Satisfaction in Britain. British Journal of Industrial Relations, 34: $189-217$.

Clark, A. (1997). Job Satisfaction and Gender: Why are Women so Happy in Work. Labour Economics, 4:341-372.

Drydakis, N. (2010). Health-Impairments and Labour Market Outcomes. European Journal of Health Economics, 11:457-469

Faragher, E. B. Cass, M. and Cooper, C. L. (2005). The Relationship Between Job Satisfaction and Health: A Meta-Analysis. Occupational and Environmental Medicine, 62:105-112.

Frederick, S. and Loewenstein, G. (1999). Hedonic Adaptation, in Kahneman, D. Diener, E. and Schwarz, N. (Eds.), Well-being: The foundation of Hedonic Psychology (p. 302329). New York: Russell Sage Foundation. 
Irwin, M. Artin, K. H. and Oxman, M. N. (1999). Screening for Depression in the Older Adult: Criterion

Validity of the 10-item Center for Epidemiological Studies Depression Scale (CES-D). Archives of Internal Medicine, 159: 1701-4.

Gazioglu, S. and Tansel, A. (2006). Job Satisfaction in Britain: Individual and Job Related Factors. Applied Economics, 38:1163 -1171.

Green, F. (2010). Well-Being, Job Satisfaction and Labour Mobility. Labour Economics, 17:897-903.

Law, K. S. and Wong, C. S. (1998). Relative Importance of Referents on Pay Satisfaction: A Review and Test of a New Policy-Capturing Approach. Journal of Occupational and Organizational Psychology, 71:47-60.

Likert, R. (1932). A Technique for the Measurement of Attitudes. Archives of Psychology, $140: 1-55$.

Locke, E. A. (1976). The Nature and Causes of Job Satisfaction. In M. D. Dunnette (Ed.). Handbook of Industrial and Organisational Psychology. Chicago: Rand McNally. 
Locke, E. A. (1984). Job Satisfaction. In Gruneberg, M. and Wall. T, (Eds.), Social Psychology and Organizational Behaviour (p. 92-117). London: John Willey and Sons.

Lucas, R. E. Clark, A. E. Diener, E. and Georgellis, Y. (2003). Re-Examining Adaptation and the Setpoint Model of Happiness: Reactions to Changes in Marital Status. Journal of Personality and Social Psychology, 84:527-539.

Oswald, A. J. and Powdthavee, N. (2008). Does Happiness Adapt? A Longitudinal Study of Disability with Implications for Economists and Judges. Journal of Public Economics, 92:1061-1077.

Renaud, S. (2002). Rethinking the Union Membership/Job Satisfaction Relationship: Some Empirical Evidence in Canada. International Journal of Manpower, 23:137-150.

Rain, J. S. Lane, I. M. and Steiner, D. D. (1991). A Current Look at the Job Satisfaction/Life Satisfaction Relationship: Review and Future Considerations. Human Relations, 44:287-307.

Rivers, D. and Vuong, Q. (1988). Limited Information Estimations and Exogeneity Tests for Simultaneous Probit Models. Journal of Econometrics, 39: 347-366. 
Shenkman, G. and Shmotkin D. (2011) Mental Health Among Israeli Homosexual Adolescents and Young Adults. Journal of Homosexuality, 58:97-116.

Sousa-Poza, A. and Souza-Poza, A. A. (2003). Gender Differences in Job Satisfaction in Great Britain, 1991-2000: Permanent or Transitory? Applied Economics Letters, 10:691-694.

Stanbury, J. P. Ried, L. D. and Velozo, C. A. (2006). Unidimensionality and Bandwidth in the Center for Epidemiologic Studies Depression (CES-D) Scale. Journal of Personality Assessment, 86:10-22.

Uppal, S. (2005). Disability, Workplace Characteristics and Job Satisfaction. International Journal of Manpower, 26:336-349.

Woodridge, J. (2002). Econometric Analysis of Cross Section Panel Data. Cambridge, MA: The MIT Press. 